\title{
INTRODUCTION AND CULTIVATION OF CHINESE HEMLOCK (TSUGA CHINENSIS) AND ITS RESISTANCE TO HEMLOCK WOOLLY ADELGID (ADELGES TSUGAE)
}

\author{
by Peter Del Tredici ${ }^{1}$ and Alice Kitajima ${ }^{2}$
}

\begin{abstract}
Chinese hemlock (Tsuga chinensis) is native to mountainous regions in eastern, central, and southwestern China. Interest in the species has recently increased because of its potential resistance to hemlock woolly adelgid (HWA) (Adelges tsugae), an introduced insect that has been killing eastern hemlock (T. canadensis) in the eastern portions of its range since the 1980s. Despite the fact that Chinese hemlock was introduced into cultivation in 1901, its environmental tolerances are still largely unknown. This study reports on the performance of Chinese hemlock seedlings planted within a native stand of eastern hemlock ( $T$. canadensis) at the Arnold Arboretum in Boston, Massachusetts, U.S., that was heavily infested with HWA. In comparison with a control group of eastern hemlock, Chinese hemlock seedlings were completely resistant to HWA damage after 4 years of exposure. The results of our investigation indicate that T. chinensis is fully hardy in USDA zone 6 and is a suitable replacement for $T$. canadensis in landscape situations because of its rapid growth rate, tolerance of shade, and resistance to HWA.

Key Words. Adelges tsugae; host resistance; integrated pest management (IPM); plant health; Tsuga canadensis; Tsuga chinensis.
\end{abstract}

The hemlock woolly adelgid (Adelges tsugae Annand) (HWA) is an introduced insect from Asia that was first discovered feeding on eastern (Canadian) hemlock (Tsuga canadensis (L.) Carrière) in Virginia, U.S., in the 1950s (Gouger 1971). It did not become a serious problem on the east coast until the 1980s when it started killing entire populations of both wild and cultivated trees in the mid-

Atlantic region of the

United States. HWA is

now well established in

the eastern portion of

the range of eastern

hemlock, from New

Hampshire south to

North Carolina

(McClure 1990; Orwig

et al. 2002), as well as

in most of the range of

Carolina hemlock ( $T$.

caroliniana Engelm.).
Table 1. Comparison of the environmental tolerance factors of various Tsuga species cultivated at the Arnold Arboretum, including shade tolerance, relative growth rate (compared to other hemlocks), cold hardiness, and HWA resistance.

\begin{tabular}{|c|c|c|c|c|c|}
\hline Species & Range & $\begin{array}{l}\text { Shade } \\
\text { tolerance }\end{array}$ & $\begin{array}{l}\text { Relative } \\
\text { growth rate }\end{array}$ & $\begin{array}{l}\text { Hardiness to } \\
\text { USDA zone } 6\end{array}$ & $\begin{array}{l}\text { HWA } \\
\text { resistance }\end{array}$ \\
\hline Tsuga canadensis & Eastern North America & Yes & Fast & Yes & No \\
\hline Tsuga caroliniana & $\begin{array}{l}\text { Southern Appalachian } \\
\text { Mountains }\end{array}$ & Yes & Moderate & Yes & No \\
\hline Tsuga chinensis & Central and western China & Yes & Fast & Yes & Yes \\
\hline Tsuga diversifolia & $\begin{array}{l}\text { Central and northern } \\
\text { Honshu, Japan }\end{array}$ & Yes & Slow & Yes & Yes \\
\hline Tsuga heterophylla & Northwestern North America & Yes & Fast & Questionable & Questionable \\
\hline Tsuga mertensiana & Northwestern North America & Unknown & Slow & Yes & Unknown \\
\hline Tsuga sieboldii & $\begin{array}{l}\text { Central and southern } \\
\text { Honshu, Japan }\end{array}$ & Yes & Moderate & Yes & Questionable \\
\hline
\end{tabular}

While there has been considerable research on the chemical and biological control of HWA on eastern and Carolina hemlock (McClure 1995; McClure et al. 2000), relatively little work has been done on the question of the resistance of other hemlock species to the insect. In one experiment, McClure (1992) found that one Japanese species (T. diversifolia (Maxim.) Mast.) and two species from western North America (T. heterophylla (Raf.) Sarg. and T. mertensiana (Bong.) Carrière) showed resistance to HWA relative to $T$. canadensis and T. caroliniana when all five species were cultivated outdoors in Connecticut for 1 year. Subsequent fieldwork on native hemlock populations in Asia has shown that HWA occurs at relatively low densities in natural populations of $T$. diversifolia and T. sieboldii Carrière in Japan (McClure et al. 2000) and T. chinensis (Franch.) E. Pritz. in China (Montgomery et al. 2000), observations that are explained by a combination of host resistance and the presence of natural predators. Bentz et al. (2002) reported that cultivated specimens of T. diversifolia and $T$. chinensis growing in close proximity to infected plants of T. canadensis in Washington, D.C., and Philadelphia, Pennsylvania, showed strong resistance to HWA over an 8-year period of exposure, while a second Japanese species, T. sieboldii, showed variable levels of damage. The existing literature on HWA resistance of various hemlock species is summarized in Table 1. 
Attention in this paper is focused on Chinese hemlock, T. chinensis, which has been little studied outside its native habitat because of limited commercial availability. Active research on Chinese hemlock has been underway at the Arnold Arboretum for the past 10 years to assess its suitability as a replacement for $T$. canadensis in landscape situations. The present study has three primary goals: to (1) reconstruct the history of introduction of $T$. chinensis into cultivation in North America, (2) document its resistance to HWA and (3) delineate its environmental tolerances.

\section{CHINESE HEMLOCK IN CULTIVATION}

While T. chinensis has a widespread distribution in mountainous regions of eastern, central, and southwestern China between 1,000 and 3,500 m (3,282 to 11,487 ft) (Wu and Raven 1999), the species is poorly represented in North American botanical gardens. E.H. Wilson is credited with the introduction of Chinese hemlock into cultivation with seed he collected in Xing Shan, Hubei Province in October 1901 (collection \# 952), while working for the Veitch Nursery Company of Chelsea, England (Sargent 1913-1917, 2:38; Rehder 1940; Clausen and $\mathrm{Hu}$ 1980; Howard 1980). One of the very few specimens of $T$. chinensis of known provenance is growing at the Arnold Arboretum of Harvard University, under accession \#17569. Wilson collected this plant as a seedling in Fang Xian, Hubei Province, China, in September 1910 and sent it to the Arnold Arboretum, where it arrived in February, 1911 (Sargent 1913-1917, 3:446; Howard 1980). As of winter 2004, Wilson's tree was $15 \mathrm{~m}$ (49.2 ft) tall with a diameter at breast height (dbh) of $37 \mathrm{~cm}$ (14.4 in.) and a branch spread of $12 \mathrm{~m}(39.4 \mathrm{ft})$, and showed no sign of adelgid infestation.

Over the years, Arnold Arboretum staff had propagated both seedlings and cuttings from the Wilson tree and distributed them to various botanical gardens and nurseries in the United States. Between 1915 and 1945, arboretum records show at least 16 separate distributions of $T$. chinensis \#17569, involving a total of 28 plants. Many of the older Chinese hemlocks now growing in botanical collections in the United States are the direct descendants of Wilson's Hubei seedling.

Apart from Wilson's collections in 1901 and 1911, wildcollected germplasm of $T$. chinensis does not appear to have entered North America until 1979 and 1980, when visiting delegations of Chinese botanists presented their hosts with seed of Tsuga chinensis from the Chinese Academy of Forestry. Since then, numerous American and European expeditions to China have collected and distributed seeds of $T$. chinensis from wild populations growing at altitudes between 1,000 and 2,650 $\mathrm{m}$ (3,282 and 8,697 ft) in Sichuan, Hubei, Shaanxi, Fujian, Zhejiang, and Yunnan provinces (Table 2).

\section{SITE CONDITIONS, PLANT MATERIALS, AND METHODOLOGY}

The Hemlock Hill portion of the Arnold Arboretum consists of approximately 10 ha (22 ac). The north-facing slope is covered with a nearly pure stand of $T$. canadensis. Bedrock is close to the surface on much of Hemlock Hill, and the soils that overlay it are well-drained and nutrient poor. Four soil samples collected from the north-facing slope of Hemlock Hill were analyzed in May 2003 and showed pH levels between 4.2 and 4.5 , organic matter content between $11.3 \%$ and $19.5 \%$, and high levels of ammonium and low levels of nitrate (Del Tredici et al. 2003).

HWA was first discovered on Hemlock Hill in April of 1997, and the pest has spread rapidly throughout the hemlock population, which consisted of some 1,905 individuals with dbh's greater than $5 \mathrm{~cm}$ (2 in.). The entire population was labeled, mapped, and qualitatively assessed for condition and HWA damage during the winter of 19971998. Eastern hemlocks along the base of Hemlock Hill have been sprayed annually in the fall with dormant oil since 1997, which has effectively protected them from HWA. Eastern hemlocks growing on the interior portions of Hemlock Hill have been left untreated and are now in a serious state of decline. When the entire population was recensused during the winter of 2002-2003, 263 trees were found to have been removed (all were either dead or near death), and those remaining had lost foliage and were in poor health (Del Tredici et al. 2003). Table 3 shows the dramatic decline in the condition of the hemlocks that occurred between 1998 and 2002 as a result of the HWA infestation.

The senior author undertook a study of the resistance of T. chinensis to HWA using seedlings that were raised from a lot of seed purchased from Sheffield Seed Company in Locke, New York, in February 1994 (lot \# 9101, received from the China National Seed Company in March 1992). The senior author determined that the seed, while of unknown provenance, was collected from trees growing in the wild. At the Arnold Arboretum, the Sheffield seed was accessioned under \#100-94 and given a 3-month coldstratification period, after which it was sown in a warm greenhouse. In April 1999, 74 five-year-old seedlings were planted out on the arboretum grounds. At the time, they were growing in $12 \mathrm{~L}$ ( 3 gal) containers and were between 60 and $110 \mathrm{~cm}$ (23.4 and 42.9 in.) tall. To specifically test the resistance of $T$. chinensis to HWA, some 42 of the seedlings were planted on the interior portions of the Hemlock Hill section of the arboretum in groups of three to six individuals in scattered light-gaps. The canopy for all the seedlings consisted of eastern hemlocks that were badly infected with HWA. 
Table 2. List of Tsuga chinensis accessions received by Arnold Arboretum that originated in China between 1901 and 2002. See text for details.

\begin{tabular}{|c|c|c|c|c|c|}
\hline$\underline{\text { Source }}$ & Collection no. and (date) & Collection location & Altitude (m) & $\begin{array}{l}\text { Arnold Arboretum } \\
\text { accession no. }\end{array}$ & $\begin{array}{l}\text { No. living } \\
\text { plants }(2004)\end{array}$ \\
\hline $\begin{array}{l}\text { Veitch China Exp. } \\
\text { (1899-1902) }\end{array}$ & EHW \#952 (1901) & Xing Shan, Hubei Province & 2,130 & 6851 (Nov. 1907) & $0($ died 1921) \\
\hline $\begin{array}{l}\text { Arnold Arboretum Exp. } \\
\text { (1910-1911) }\end{array}$ & EHW \# 4453 (1910) & Fang Xian, Hubei Province & $2,300-3,000$ & $\begin{array}{l}17569(=6851-1) \\
\text { (Feb. 1911) }\end{array}$ & 1 (grounds) \\
\hline $\begin{array}{l}\text { Botanic Garden, Sun Yat-Sen } \\
\text { Memorial Park (Nanjing) }\end{array}$ & $(1932,1934)$ & Sichuan Province & - & $394-32 ; 534-34$ & 0 \\
\hline Chinese Academy of Forestry & $(1979,1980)$ & Sichuan Province $\left(31^{\circ} \mathrm{N} ; 103^{\circ} \mathrm{E}\right)$ & $1,000-1,300$ & $1291-79 ; 481-80$ & 0 \\
\hline Shanghai Botanical Garden & $(1980)$ & Zhejiang Province & - & $664-81$ & 0 \\
\hline Quarryhill Botanical Garden & $(1991,1992)$ & Sichuan Province & $2,070-2,500$ & $466-95 ; 92-93$ & 0 \\
\hline U.S. National Arboretum & (1992) & Wild source & - & $233-2003$ & 5 (nursery) \\
\hline Sheffield Seed Co. & $\begin{array}{l}\text { China Natl. Tree Seed Co. } \\
\text { (1992) }\end{array}$ & Wild source & - & $100-94$ & 75 (grounds) \\
\hline Xian Botanical Garden & $(1994,1996)$ & Ningshaan, Shaanxi Province & $1,600-1,900$ & $503-94 ; 65-96$ & 10 (grounds) \\
\hline NACPEC Exp. (Qingling Mts.) & $\begin{array}{l}\text { QLG-013, 188, 190, } 193 \\
216,217(1996)\end{array}$ & Ningxi Reserve; Shaanxi Province & $1,800-2,200$ & $\begin{array}{l}20-99 ; 21-99 ; \\
227 \text { to } 232-2003\end{array}$ & $\begin{array}{l}13 \text { (grounds); } \\
26 \text { (nursery) }\end{array}$ \\
\hline $\begin{array}{l}\text { Cui and Ma } \\
\text { (Xian Botanical Garden) }\end{array}$ & CUI 97-053; 97-054 (1997) & Shaanxi Province & - & $\begin{array}{l}242,243-2000 \\
307,308-2000 \\
225,226-2003\end{array}$ & $\begin{array}{l}28 \text { (grounds); } \\
14 \text { (nursery) }\end{array}$ \\
\hline USDA Forest Service & $(2002)$ & Wenbishan; Yunnan Province & 2,650 & $439-2003$ & Greenhouse \\
\hline USDA Forest Service & $(2002)$ & Ningshan Co.; Shaanxi Province & 1,800 & $440-2003$ & Greenhouse \\
\hline
\end{tabular}

Table 3. Comparison of the condition ratings of the 1,905 eastern hemlocks [with dbh's greater than $5 \mathrm{~cm}(2 \mathrm{in}$.$) ]$ growing on Hemlock Hill at the Arnold Arboretum between 1998 and 2002. Condition ratings were performed both years by the same staff members.

\begin{tabular}{llrlrl}
\hline $\begin{array}{l}\text { Year } \\
\text { sampled }\end{array}$ & Excellent* & Good & Fair & Poor & $\begin{array}{l}\text { Dead or } \\
\text { removed }\end{array}$ \\
\hline 1998 & 249 & 1,406 & 163 & 87 & - \\
2002 & 10 & 68 & 422 & 1,142 & 263 \\
\hline
\end{tabular}

*Excellent = outstanding specimen; good = healthy specimen, no evidence of disease or physical damage; fair = specimen in decline, evidence of disease or physical damage; poor $=$ specimen in poor condition, more dead branches than living.

On June 25 and 26, 2003, the authors evaluated the growth and resistance of 38 of the 42 Chinese hemlocks that had been planted on Hemlock Hill in 1999. Four individuals were left out of the study because they were not able to be located at the time of the evaluation. As a "control" group, the authors tagged some 33 seedlings of $T$. canadensis that were growing spontaneously on the northfacing slope of Hemlock Hill, adjacent to the planted Chinese hemlocks. The fact that only 33 seedlings could be located on the north-facing slope is testament to the paucity of natural hemlock regeneration and explains why some of the plants used in this study were larger than optimal [up to $380 \mathrm{~cm}$ (148.2 in.) tall]. The major differences between the two trial groups were as follows: The T. chinensis seedlings had 4 years of exposure to HWA, while the T. canadensis seedlings had 6 ; and the majority of T. chinensis seedlings (68\%) were growing in light gaps that received some direct sunlight during the day, while the majority of $T$. canadensis seedlings (94\%) were growing in understory positions that did not receive any direct sunlight.

The authors measured the heights of the $38 \mathrm{~T}$. chinensis and 33 T. canadensis seedlings and recorded their canopy position, which was rated as "sun" (growing in a large canopy gap with moderate amounts of direct sun), "gap" (growing in a small canopy gap with minimal amounts of direct sun), or "shade" (growing in complete shade). To assess the level of infestation with HWA, two branches on opposite sides of each tree were selected at random, and the six top-most shoots on each branch, consisting of growth from both 2002 and 2003, were selected for evaluation. For each of the 12 shoots per tree, the authors (1) measured its length to the nearest millimeter, (2) counted the number of HWA egg sacs, (3) noted the presence or absence of new (2003) growth, and (4) noted the presence or absence of spider mite damage. The cottony HWA egg sacs were counted with the naked eye on the undersides of the 2002 shoots, and spider mite damage was assessed by looking for the characteristic leaf stippling on the uppersides of the 2002 shoots (Montgomery 2003).

The senior author recensused the 38 Chinese hemlock seedlings on March 9, 2004, in order to obtain final height 
Table 4. Means and standard deviations for shoot length, HWA egg sacs, percentage of new growth, and mite damage on matched populations of Tsuga chinensis and T. canadensis growing at the Arnold Arboretum.

\begin{tabular}{|c|c|c|c|c|c|c|c|c|c|}
\hline \multirow[b]{2}{*}{ Species } & \multirow{2}{*}{$\begin{array}{l}\text { No. seedlings } \\
\text { sampled }\end{array}$} & \multirow{2}{*}{$\begin{array}{l}\text { Mean plant } \\
\text { height }(\mathrm{cm})\end{array}$} & \multicolumn{3}{|c|}{ Exposure } & \multirow{2}{*}{$\begin{array}{l}\text { Mean shoot } \\
\text { length }(\mathrm{cm})^{*}\end{array}$} & \multirow{2}{*}{$\begin{array}{l}\text { Mean no. HWA } \\
\text { egg sacs per shoot }\end{array}$} & \multirow{2}{*}{$\begin{array}{l}\text { Mean \% shoots } \\
\text { w/new growth }\end{array}$} & \multirow{2}{*}{$\begin{array}{l}\text { Mean \% shoots } \\
\text { w/mite damage }\end{array}$} \\
\hline & & & Sun & Gap & Shade & & & & \\
\hline Tsuga chinensis & 38 & $\begin{array}{l}169.0 \pm 38.0 \\
(\text { range }=84 \\
\text { to } 240 \mathrm{~cm})\end{array}$ & 8 & 18 & 12 & $\begin{array}{l}10.3 \pm 3.5 \\
(\text { range }=5.5 \\
\text { to } 17.2)\end{array}$ & 0 & 100 & $\begin{array}{l}8.7 \pm 24.7 \\
\text { (range }=0 \\
\text { to } 92 \text { ) }\end{array}$ \\
\hline Tsuga canadensis & 33 & $\begin{array}{l}182.6 \pm 94.5 \\
(\text { range }=45 \\
\text { to } 380 \mathrm{~cm})\end{array}$ & 2 & 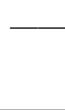 & 31 & $\begin{array}{l}4.9 \pm 1.2 \\
\text { (range }=2.7 \\
\text { to } 8)\end{array}$ & $\begin{array}{l}3.8 \pm 4 \\
\text { (range }=0 \\
\text { to } 14.7 \text { ) }\end{array}$ & $\begin{array}{l}45.4 \pm 38.8 \\
\text { (range }=0 \\
\text { to } 100)\end{array}$ & $\begin{array}{l}20.9 \pm 27.6 \\
\text { (range }=0 \\
\text { to } 100)\end{array}$ \\
\hline
\end{tabular}

* Based on samples of 12 shoots per tree.

measurements for the 2003 growing season and to assess their survival following an extremely cold winter when the temperature at the arboretum reached a low of $-22.5^{\circ} \mathrm{C}$ $\left(-8.5^{\circ} \mathrm{F}\right)$ on January 16.

\section{RESULTS AND DISCUSSION}

Results of this study are summarized in Table 4. The most dramatic finding was the total absence of HWA egg sacs on any of the $38 \mathrm{~T}$. chinensis seedlings in comparison to a mean of 45.9 egg sacs per 12-shoot sample for T. canadensis. Another indicator of $T$. chinensis resistance to HWA was the difference in new growth between the two species. One hundred percent of the terminal buds on sampled shoots of T. chinensis produced new growth compared with only $45 \%$ for $T$. canadensis. Lastly, the mean shoot length for T. chinensis was $10.3 \mathrm{~cm}$ (4 in.), more than twice the $4.9 \mathrm{~cm}$ (1.9 in.) length recorded for $T$. canadensis. These results clearly indicate that Chinese hemlock possesses a high degree of resistance to HWA under conditions that were optimal for infestation of eastern hemlock. This conclusion supports anecdotal reports of Chinese hemlock's resistance to HWA (Montgomery et al. 2000; Bentz et al. 2002).

The remeasurement of the 38 Chinese hemlocks on March 9, 2004, showed them to be 17\% taller than they were in the summer, when their shoot tips were drooping, with an average height of $197.8 \pm 50.7 \mathrm{~cm}(77.1 \pm 19.8 \mathrm{in}$.). Given that the seedlings averaged between 80 and $90 \mathrm{~cm}$ (31.2 and 35.1 in.) tall when they were planted out in April 1999, the average increase in height for $T$. chinensis over four growing seasons has been over a meter (Figure 1). This was a remarkable figure given the shady conditions on Hemlock Hill, the thin soil, and the minimal after-care the plants received. Finally, it should be noted that the plants showed very little winter damage at the time of the March resurvey, despite the low temperatures recorded in January 2004.

The results of this study indicate that T. chinensis is fully hardy in USDA zone 6 and is a suitable replacement for T. canadensis in landscape situations because of its relatively rapid growth rate, tolerance of shade, and resistance to HWA.

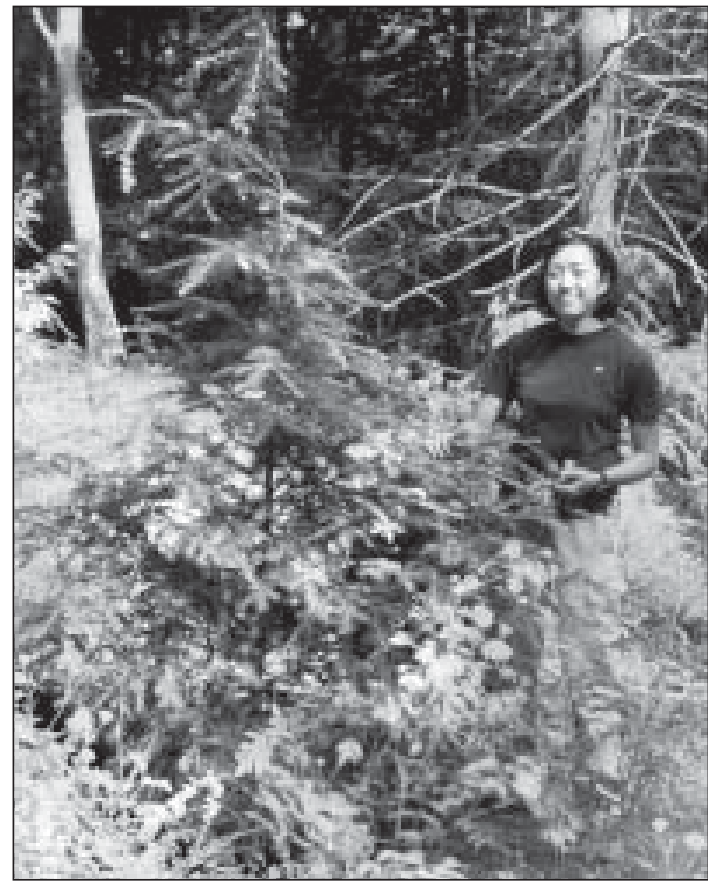

Figure 1. One of the Tsuga chinensis seedlings (AA \#100-94) growing in a canopy gap on Hemlock Hill at the Arnold Arboretum. Photographed in summer 2003.

\section{LITERATURE CITED}

Bentz, S.E., L.G.H. Riedel, M.R. Pooler, and A.M.

Townsend. 2002. Hybridization and self-compatibility in controlled pollinations of eastern North American and Asian hemlock (Tsuga) species. J. Arboric. 28(4):200205.

Clausen, K.S., and S.Y. Hu. 1980. Mapping the collecting localities of E.H. Wilson in China. Arnoldia 40(3): 139-145.

Del Tredici, P., T. Akin, J. Coop, J. DelRosso, R. Ervin, S. Kelley, A. Kitajima, J. Papargiris, and K. Port. 2003. Proposed Hemlock Hill Management Plant. Arnold Arboretum Living Collections Department, internal report. Jamaica Plain, MA. 
Gouger, R.J. 1971. Control of Adelges tsugae on hemlock in Pennsylvania. Sci. Tree Topics 3:1-9.

Howard, R.A. 1980. E.H. Wilson as a botanist (part I). Arnoldia 40(3): 102-138.

McClure, M.S. 1990. Role of wind, birds, deer, and humans in the dispersal of hemlock woolly adelgid (Homoptera: Adelgidae). Environ. Entomol. 20:258-264.

- 1992. Hemlock woolly adelgid. Am. Nurseryman 175(6):82-89.

— 1995. Managing hemlock woolly adelgid in ornamental landscapes. Bulletin of the Connecticut Agriculture Experiment Station \# 925. New Haven, CT. McClure, M.S., C.A. Cheah, and T.C. Tigner. 2000. Is Pseudoscymnus tsugae the solution to the hemlock woolly adelgid problem? An early perspective, pp 89-96. In McManus, K.A., K.S. Shields, and D.R. Souto (Eds.). Proceedings: Symposium on Sustainable Management of Hemlock Ecosystems in Eastern North America, 22-24 June 1999, Durham, NH. GTR-NE-267. USDA Forest Service, Northeastern Research Station, Newtown Square, PA.

Montgomery, M. E. 2003. Research scientist, USDA Forest Service, Camden, CT. Personal communication.

Montgomery, M.E., D. Yao, and H. Wang. 2000. Chinese Coccinellidae for biological control of the hemlock woolly adelgid: Description of native habitat, pp 97102. In McManus, K.A., K.S. Shields, and D.R. Souto (Eds.). Proceedings: Symposium on Sustainable Management of Hemlock Ecosystems in Eastern North America, 22-24 June 1999, Durham, NH. GTR-NE-267. USDA Forest Service, Northeastern Research Station, Newtown Square, PA.
Orwig, D.A., D.R. Foster, and D.L. Mausel. 2002. Landscape patterns of hemlock decline in New England due to the introduced hemlock woolly adelgid. J. Biogeog. 29:1475-1488.

Rehder, A. 1940. Manual of Cultivated Trees and Shrubs (2nd ed.). Macmillan, New York, NY.

Sargent, C.S. (Ed.). 1913-1917. Plantae Wilsonianae. An Enumeration of the Woody Plants Collected in Western China for the Arnold Arboretum of Harvard University During the Years 1907, 1908, and 1910 by E.H. Wilson. Cambridge University Press, Cambridge, MA.

Wu, Z.-Y., and P.H. Raven (Eds.). 1999. Flora of China (Vol. 4). Science Press, Beijing, China, and Missouri Botanical Garden Press, St. Louis, MO.

Acknowledgments. The authors would like to thank Arnold Arboretum staff members Tom Akin, Julie Coop, John DelRosso, Bob Ervin, Susan Kelley, Jim Papargiris, and Kyle Port, whose work on the Hemlock Hill project made this study possible; Mike Montgomery of the USDA Forest Service, Northeast Region, for providing details on protocols for counting HWA; and Nathan Havill for his helpful comments on a draft of the manuscript.

\author{
${ }^{1 *}$ Senior Research Scientist \\ Arnold Arboretum of Harvard University \\ 125 Arborway \\ Jamaica Plain, MA 02130, U.S. \\ ${ }^{2}$ Plant Records Coordinator \\ Descanso Gardens \\ 1418 Descanso Drive \\ La Canada Flintridge, CA 91011, U.S.
}

*Corresponding author. 
Résumé. La pruche de Chine (Tsuga chinensis) est originaire des régions montagneuses de l'Est, du Centre et du Sud-Ouest de la Chine. Lintérêt envers cette espèce s'est accrû récemment en raison de son potentiel de résistance au puceron lanigère de la pruche (Adelges tsugae), un insecte introduit qui tue les pruches du Canada (T. canadensis) dans les régions orientales de son aire de distribution depuis les années '80. En dépit du fait que la pruche de Chine a été introduite en culture depuis 1901, sa tolérance environnementale est toujours encore méconnue. Cette étude traite de la performance des semis de pruche de Chine plantés au sein d'un peuplement indigène de pruches du Canada (T. canadensis) de l'arboretum Arnold de Boston au Massachusetts et qui a été lourdement infesté par le puceron lanigère en question. Comparativement avec une groupe-témoin de pruches du Canada, les semis de pruche de Chine étaient totalement résistants aux dommages causés par le puceron lanigère de la pruche, et ce après quatre ans d'exposition. Les résultats de notre étude indiquent que $T$. chinensis est pleinement rustique en zone 6 du USDA et constitue un remplaçant approprié pour $T$. canadensis dans les aménagements paysagers en raison de sa croissance rapide, de sa tolérance à l'ombre et de sa résistance au puceron lanigère de la pruche.

Zusammenfassung. Die chinesische Schierlingtanne Tsuga chinensis ist in den Bergregionen von Ost-, Zentralund Südwestchina beheimatet. Das Interesse an dieser Art hat kürzlich zugenommen wegen ihrer potentiellen Resistenz gegenüber der Wollschildlaus Adelges tsugae, einem eingeführten Schadinsekt, welches an der östlichen Schierlingstanne T. Canadensis seit den 80ger Jahren zu großem Absterben geführt hat. Trotz der Tatsache, dass die chinesische Schierlingtanne um 1901 in die Kultivierung eingeführt wurde, sind ihre Umwelttoleranzen noch weitgehend ungekannt. Diese Studie berichtet über die Leistung von Sämlingen der chinesische Schierlingtanne an dem heimischen Standort von der östlichen Schierlingstanne am Arnold Arboretum in Boston, USA, welche heftig von den Schadinsekten befallen sind. Im Vergleich zu einer Kontrollgruppe von östlichen Schierlingstannen waren die chinesische Schierlingtannen über einen Zeitraum von 4 Jahren vollkommen resistent gegenüber den Insekten. Die Ergebnisse unserer Untersuchung weisen darauf hin, dass Tsuga chinensis in den USA in der Zone 6 völlig immun ist und wegen seiner schnellen Wachstumsrate, Schattentoleranz und Widerstand gegen Adelges tsugae ein geeigneter Ersatz für $T$. canadensis ist.

Resumen. El abeto chino (Tsuga chinensis) es nativo de las regiones montañosas del este, centro y suroeste de China. El interés en esta especie ha aumentado debido a su resistencia potencial al aldégido (Adelges tsugae), un insecto introducido que ha estado matando desde 1980 al abeto del este ( $T$. canadensis) en la porciones orientales de su rango. A pesar del hecho de que el abeto chino fue introducido como cultivo en 1901, sus tolerancias ambientales son aún en gran parte desconocidas. Este estudio reporta el comportamiento de brinzales de abeto chino plantados en rodales nativos de abetos del este (T. canadensis) en el Arboretum Arnold en Boston, MA, que estuvo fuertemente infestado con el aldégido. En comparación con un grupo de control de abeto del este, los brinzales de abeto chino fueron completamente resistentes al daño de Adelges tsugae después de cuatro años de exposición. Los resultados de nuestra investigación indican que T. chinensis es resistente en la zona 6 de la USDA y es un reemplazo en el paisaje aceptable para $T$. Canadensis debido a su tasa rápida de crecimiento, tolerancia a la sombra y resistencia a Adelges tsugae. 